\begin{tabular}{lr} 
DE & $\begin{array}{l}\text { DE GRUYTER } \\
\text { OPEN }\end{array}$ \\
\hline U & STUDIA UNIVERSITATIS BABES,BOLYAI OECONOMICA \\
VOLUME 62, ISSUE 2, 2017, pp. 77-88 \\
DOI: $10.1515 /$ subboec-2017-0010
\end{tabular}

\title{
THE IMPACT OF THE PROBLEMS FACED BY ONLINE CUSTOMERS ON ECOMMERCE
}

\author{
Simona SABOU* \\ Technical University of Cluj-Napoca, Romania \\ Bianca AVRAM-POP \\ Technical University of Cluj-Napoca, Romania \\ Liliana Adela ZIMA \\ Technical University of Cluj-Napoca, Romania
}

\begin{abstract}
The purpose of this study is to identify the behavior of customers in the online environment. We analyzed the evolution, characteristics, advantages and disadvantages of this type of commerce, and its implications on the consumers. In order to identify the customers' behavior online, we selected three variables which are characterized by time intervals of the latest online order, and six variables which analyze the main problems faced by consumers of goods/services bought online (a long shipping time, damaged products, non-compliant products, fraud related issues, underperforming complaint system, technical issues, lack of customer and legal aspects). Online commerce is less developed in the Czech Republic, Romania, Poland, Lithuania, Ireland, Bulgaria, Estonia, Slovenia and Norway. But, the advantages of ecommerce weigh more for the consumer than the problems they face, for example: online shoppers will continue to make online purchases even if they have experienced delays in delivering goods/services, damaged products, online fraud, technical problems or difficulties in finding information about the warranty of goods/services.
\end{abstract}

JEL classification: E20, F10

Keywords: e-commerce, unsatisfied customers, European states.

\footnotetext{
${ }^{*}$ Corresponding author. Address: Faculty of Sciences, Technical University of Cluj-Napoca, North University Center in Baia Mare, Victoriei, nr. 76, 430122, Baia Mare, România, Tel. 0262-276059, E-mail: simona.sabou@gmail.com
} 


\section{Introduction}

The Electronic Data Interchange (EDI) first appeared in the 1960's and can be considered the forefather of Electronic Commerce (EC) (Antohi, 2009). Cyberspace has brought about an era during which acquisitions and sales have become more automated and more convenient, businesses have become interconnected and have also connected with their customers in a network, time and distances, which acted as commercial barriers and required high costs in the past, have shortened immeasurably, and vendors continuing to sell the old-fashioned way will disappear from the marketplace (Kotler, 2003). As the use of the internet has increased, e-commerce has become available for a great number of customers (Holdorf and Haasis, 2014), and predictions show the electronics links between companies will intensify (Benjamin and Wigand, 1995). In recent years, the Internet (and its technology) has brought about an increase in international commerce (Totonchi and Manshady, 2012). The volume of international commerce will increase through e-commerce (Terzi, 2011). Since the first online transaction, which was first performed in 1995, to the present day, e-commerce has grown rapidly (Laudon and Traver, 2013).

Consumers are ever more attracted by online shopping due to their attitude as regards saving time, price flexibility and availability of various products and a range of products on one platform (Ferri et al., 2008). Online shopping has been growing in time because more and more consumers have begun trusting online commerce and have moved a significant part of their shopping online (Lixandroiu, 2017).

The consumers in the European countries also join this evolution. But being a relatively new phenomenon, their behavior can be influenced by the various difficulties which appear in the online environment. That's exactly why we have proposed in this paper to analyze how it affects the problems encountered by online customers developing this type of commerce.

\section{Literature review}

E-commerce is a new way of doing business (Seyal and Rahman, 2003). Several authors have tried to define this notion. E-commerce represents the use of electronic devices in doing business (Choi et al., 1997) or the process of buying and selling products or services which use electronic data transmission by means of the internet (Grandon and Pearson, 2004).

Electronic commerce means using the computer and the internet when proposing businesses, including the selling, buying, and exchange of goods, services, and information (McKay and Marshall, 2004). Another definition of electronic commerce refers to the electronic exchange of information, goods, services, and payments (Harrington and Reed, 1996).

E-commerce is the enterprise of buying and selling by means of remotely sending data, which is specific to the expansive policy of the commercial companies' marketing strategy (Bucur, 2002).

Many studies have noticed the benefits and the impact of e-commerce, these being summarized as follows (Nejadirani et al., 2011): 
- it offers unmatched savings as regards transaction costs;

- it reduces advertising and promotion costs;

- it grants fast communication between the buyer and the seller;

- it minimizes transportation obstacles;

- it limits delivery costs;

- it eliminates the physical limitations of time and space.

E-commerce intensifies competition and generates advantages for the consumers, who can get lower prices due to having several options (Malkawi, 2006). Moreover, the development of global markets through the internet makes historical relations less important and suggests that countries with the least previous commercial relations have the most to gain from e-commerce, especially developing countries (Freund and Weinhold, 2004). E-commerce can add more value to enterprises and consumers in developing countries than in developed countries (Annan, 2001). The legal regulations of e-commerce are justified since its dynamics leads to the creation of a significant market, and most laws regarding ecommerce state that transactions carried out over the internet fall under the jurisdiction of the supplier's country (Bătăgan et al., 2010).

Ensuring the consumer's protection in the virtual environment, where the commercial transaction is carried out, requires the existence of new and extremely important aspects regarding the security of the consumer (Surcel and Dinu, 2007). E-commerce comprises a wide range of problems such as security, trust, reputation, legal framework, payment mechanisms, advertising, online catalogues (Haleema and lyengar, 2016).

The issues regarding security and the legal framework are the most recent problems which prevent companies from joining e-commerce (Savrul et al., 2014). One reason why consumers do not buy online, which is often mentioned, is the lack of trust (Petrovic et al., 2003). Trust has always been the underlying component, with great importance within the uncertain, internet-based environment of e-commerce (Gefen and Straub, 2003).

Within e-commerce the behavior of consumers from various areas could differ because of the geographical and cultural environment, as well as because they live in different countries and social cultures (Dabidian et al., 2016). Thus, the manner of shopping could differ very much from region to region (Zhou and Wang, 2014).

Some advice regarding safe online shopping and payments could be summarized as follows (Bătăgan et al., 2010):

- the need to take a closer look to the type of information generally requested when buying goods and services online;

- the need to be careful to the rights regarding the physical delivery of the products ordered online, the right to return the ordered products if they do not meet the requirements.

Within e-commerce, the behavior of consumers tended to be concerned mainly with functional and utilitarian considerations (Brown et al., 2003). The study of e-consumer behavior is gaining in importance due to the proliferation of online shopping (Dennis et al., 2004). The behavior of online consumers is not yet fully understood, due to the fact that there are a lot of problems that clients encounter. Therefore, in this paper, we are trying to analyze some of them. 


\section{Research Methodology}

The aim of this study is to identify the behavior of customers in the online environment - a hot topic recently. The results of this study should serve both policy makers who need to implement and adapt laws that protect both consumers, as well as companies involved in ecommerce. The latter must adapt their online sales strategies according to customer needs, both loyal and potential clients.

In order to achieve this, we selected 3 variables which are characterized by time intervals during which the latest online order was made (the last 3 months, 3-12 months, more than 1 year), and six variables which analyze the main issues consumers of goods/services bought online are faced with (long shipping time, damaged products, non-compliant products, fraud related issues, underperforming complaint system, technical issues, lack of customer and legal aspects).

All these variables are expressed in percentages (e.g.: the percentage of individuals who placed their latest ordered within the past 3 months of the total number of individuals living in the country or the percentage of individuals for whom the delivery of goods lasted longer of the total number of individuals ordering over the internet) and are related to the population of the 29 European states, the data being collected from the EUROSTAT website and referring to the year 2016.

We used graphics in order to present the three variables for each country included in the study. Moreover, in order to analyze the manner in which problems occurring within online commerce influence the buyer's decision, we want to study the relation between the time interval of the latest online order and the difficulties which occur most often in this situation, and for this we used the statistics software SPSS (Statistical Package for the Social Sciences).

\section{Outcomes and Discussions}

To begin with, it is important to identify and analyze the differences which appear amongst European states when considering the time interval of the latest online order. Thus, in figure 1 we present the percentages of individuals of the 29 European states included in the analysis who placed at least one online order within the past 3 months of the total number of individuals. One can notice in this figure that Great Britain holds the highest percentage $(78 \%)$ of individuals who purchased online a good/service within the past 3 months, while at the opposite end of the scale one can find Romania, a country where only $8 \%$ of the population made at least one online purchase over the analyzed period of time. Close to Romania, at the end of the classification, one can find countries such as: Bulgaria $(11 \%)$, Macedonia (11\%) and Turkey (13\%). As regards this percentage of individuals, we calculated the average of the 29 European states and thus obtained the value of $39 \%$. Thus we can identify the states which are bellow this value. There are 14 countries in total, amongst which: Bulgaria, the Czech Republic, Spain, Croatia, Lithuania, Hungary, Poland, Portugal, Romania, Cyprus and Turkey.

With this analysis we seek to identify the European states where e-commerce is not very well developed because certain interventions and changes need to happen here in order to generate its development. In the above list one can notice 
that the economy of most countries included here is developing (e.g.: Romania and Bulgaria), as well as the fact that there are cases where its growth is very slow (e.g.: Greece, who had to enforce some austerity measures during the recent years).

Fig. 1. Representation of the European states depending on the percentages of individuals who placed at least one order within the past 3 months

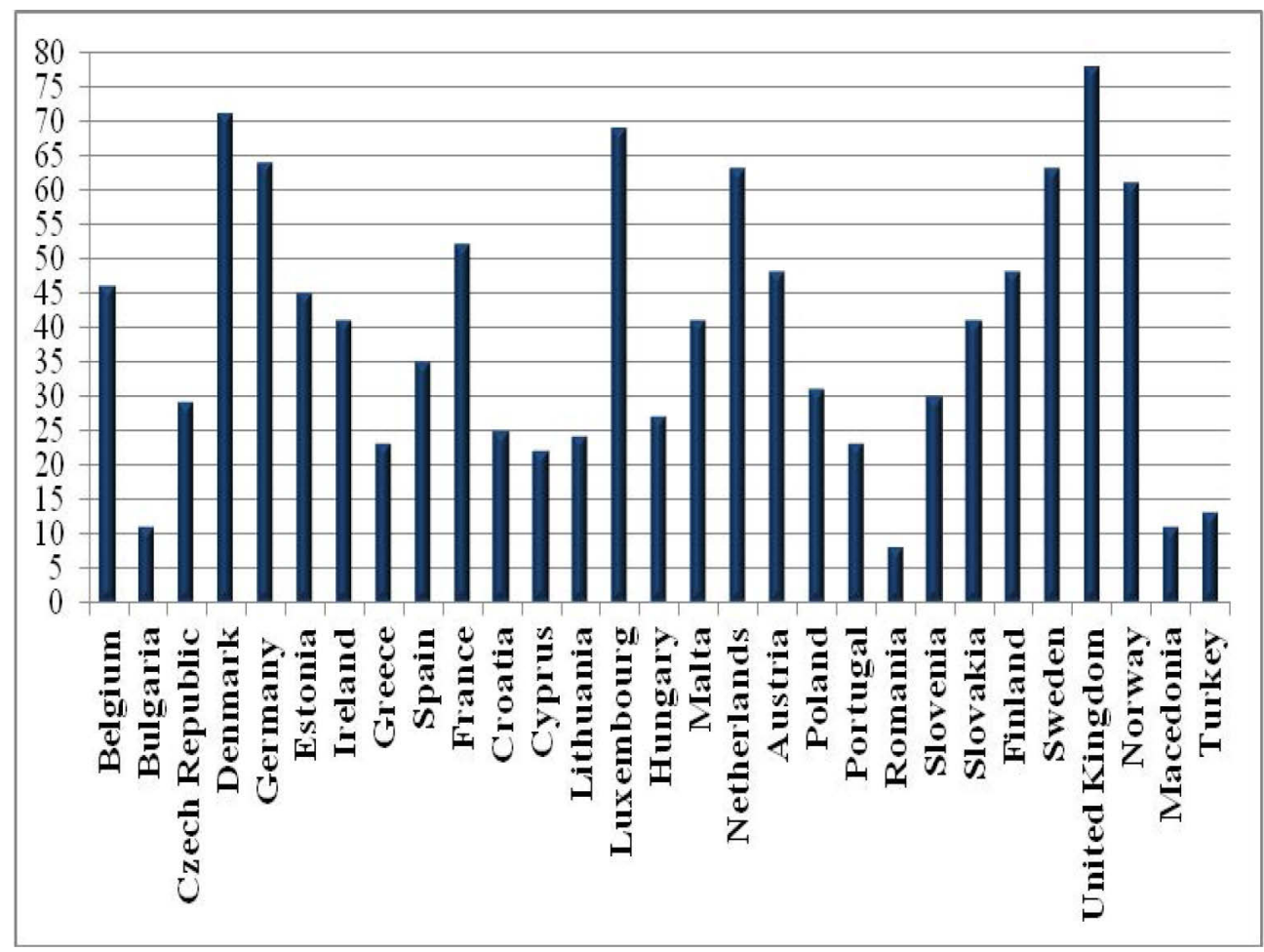

As regards the percentages of individuals who shopped online within the time interval of 3-12 months, seen in figure 2, the classification changes, the top positions being held by Finland (20\%), the Czech Republic (18\%) and Ireland $(18 \%)$, while the bottom positions are held by Romania (4\%), Macedonia $(4 \%)$, Turkey (5\%) and Great Britain (5\%). The small percentages recorded by Great Britain as regards the latest online order placed within the 3-12 month time interval and the one placed more than one year before $(2 \%$ - figure 3$)$ is due to the fact that over $70 \%$ of the individuals often shop online (at least one order within the past 3 months). As regards the other 3 states at the bottom of the hierarchy, the explanation is different and is related to the level of development in these countries. Five of the 29 European states record the average value of the sample $(10 \%)$ when speaking about the percentage of individuals who ordered a good/service online within the time interval 3-12 months. These countries are characterized by stability and a strong economy: Belgium, Denmark, Germany, Luxemburg and Austria. 
Fig. 2. Representation of the European states depending on the percentages of individuals who placed the latest order within the 3-12 months time interval

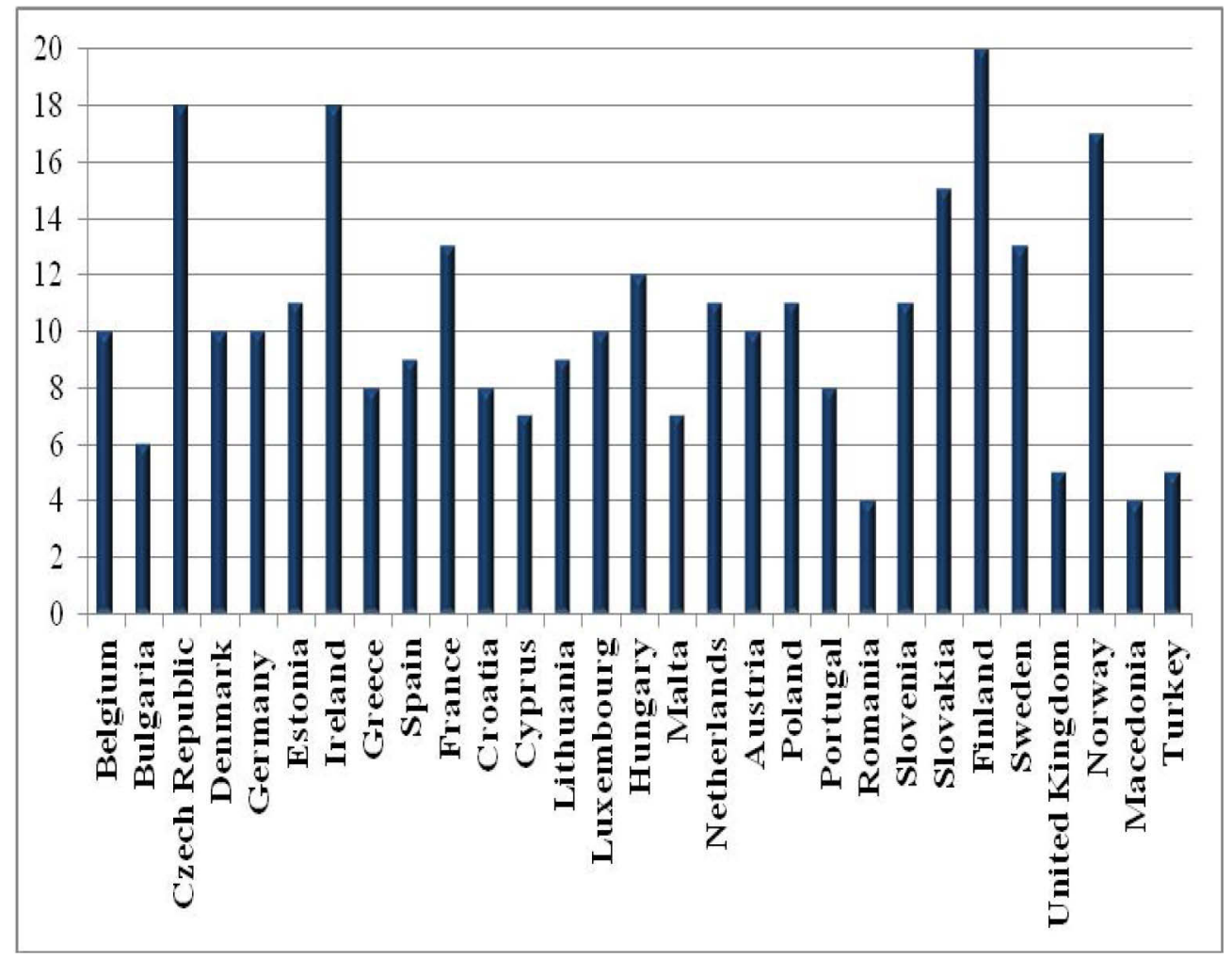

The last figure included in this paper, figure 3 , represents the percentages of individuals who have not ordered anything online for over a year. Thus the states where these values are higher, e-commerce is less developed. Here are some examples of such states: the Czech Republic, Romania, Poland, Lithuania, Ireland, Bulgaria, Estonia, Slovenia and Norway. All of the above states are characterized by percentages of individuals who order online higher than the average value of $7 \%$. 
Fig. 3. Representation of the European states depending on the percentages of individuals who placed ordered a good/service online more than one year before

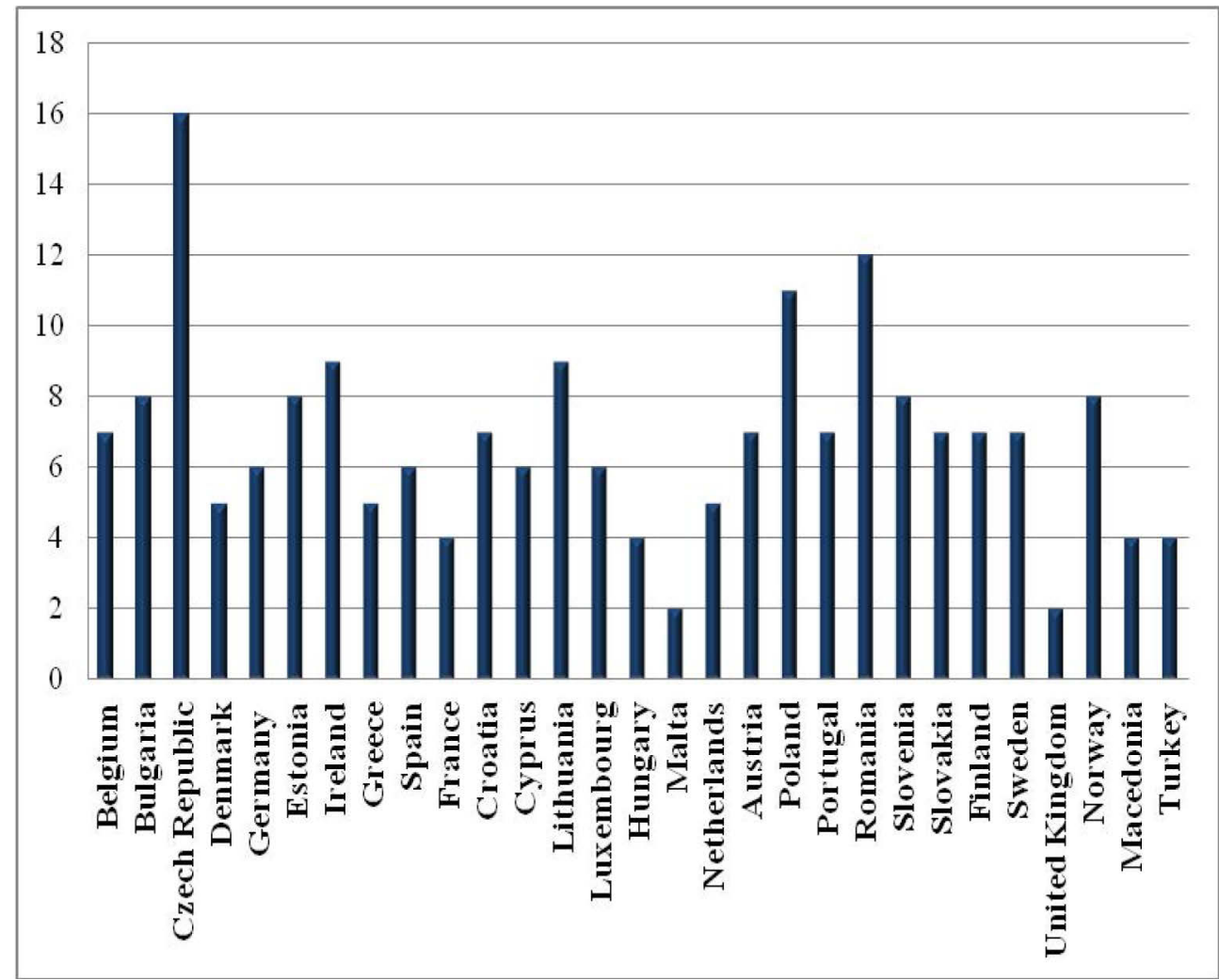

In order to better understand e-commerce in Europe, we calculated the descriptive statistics of the percentages of individuals depending on the time interval of their latest online order. If the minimal and maximal values were highlighted in the above representation of the three variables, in table 1 we calculated the range, which is the difference between the extreme values, offering an image of the scope of the data. The highest range can be found, as expected, in the percentage of individuals who placed at least one online order within the past 3 months (70), being followed at a great distance by the one for online shoppers within the past 3-12 months (16), a range which nevertheless is close to the one recorded in the case of individuals who ordered at least one good/service more than one year before (14).

The fact that the average value and the modal values are equal in all three situations can be explained by the limited size of the analyzed sample ( 29 European states). Thus the value which divides the observations in two equal parts and the one which can be found most frequently in the series of data is 41 in the case of individuals who ordered online within the past 3 months, 10 when the latest order was placed within the past 3-12 months, and 7 when the period is over on year. 
Table no. 1. Descriptive statistics of the values which describe the time interval of the latest online order

\begin{tabular}{|c|r|r|r|}
\hline & $\begin{array}{c}\text { Customers of } \\
\text { e-commerce within } \\
\text { the past 3 months }\end{array}$ & $\begin{array}{c}\text { Customers of } \\
\text { e-commerce within } \\
\text { the past 3-12 months }\end{array}$ & $\begin{array}{c}\text { Customers who } \\
\text { shopped online more } \\
\text { than 12 months before }\end{array}$ \\
\hline Range & 70 & 16 & 14 \\
\hline Mean & 39.41 & 10.3448 & 6.7931 \\
\hline Median & 41 & 10 & 7 \\
\hline Mode & 41 & 10 & 7 \\
\hline $\begin{array}{c}\text { Std. } \\
\text { Deviation }\end{array}$ & 19.785 & 4.20269 & 2.89555 \\
\hline Variance & 391.466 & 17.663 & 8.384 \\
\hline Skewness & 0.243 & 0.63 & 1.103 \\
\hline Kurtosis & -0.933 & 0.009 & 2.708 \\
\hline
\end{tabular}

In table 1 we also represented the variance and the standard deviation, yet we shall only explain the values of the latter because it represents the square root of the variance, being a more precise parameter. The standard deviation shows the average deviation of the recorded values as compared to the average values. As regards the three variables analyzed descriptively, the standard deviation (19.785 - customers of online shopping within the past 3 months, 4.20269 - customers of online shopping within the past 3-12 months, and 2.89555 - customers of online shopping more than 12 months before) is far below the average value, which means a wide spread of the studied values.

In analyzing the series of data we also used the Skewness and Kurtosis indicators. Skewness indicates the deviation of the empirical distribution in relation to a symmetrical distribution around the average, and the values higher than 0 in all three variables show that the distributions are tilted towards the left, with more extreme values towards the right. The value of the Kurtosis indicator is used in order to indicate the level of flatness of pointedness of a distribution, and is compared with value 3 . Thus all 3 variables have flatter distributions than the average and have values dispersed over a wider interval around the average.

The graphical representation of the European states as regards e-commerce serves in creating a classification which points out the top and bottom positions.

In this paper we want to carry out a more complex analysis of e-commerce in Europe, and in order to achieve this we identified in table no. 2 the correlation between the frequency of online orders and the main six problems individuals face when buying online (it takes a long time to deliver the goods/services, the goods/services are damaged are do not correspond with the ordered, fraud related issues, complaints were not solved or there was no satisfactory solution, technical problems and difficulty in finding information regarding guarantees/warranties, and other legal rights). 
Table no. 2. Spearman correlation coefficients between the time of the latest online order and the main problems customers face

\begin{tabular}{|c|c|c|c|c|}
\hline & & $\begin{array}{l}\text { Customers of } \\
\text { e-commerce } \\
\text { within the past } \\
3 \text { months }\end{array}$ & \begin{tabular}{|c|}
$\begin{array}{c}\text { Customers of e- } \\
\text { commerce within } \\
\text { the past } 3-12 \\
\text { months }\end{array}$ \\
\end{tabular} & \begin{tabular}{|c|} 
Customers who \\
shopped online \\
more than 12 \\
months before \\
\end{tabular} \\
\hline \multirow{3}{*}{$\begin{array}{l}\text { Speed of delivery } \\
\text { Ionger than indicated }\end{array}$} & \begin{tabular}{|l|} 
Correlation \\
Coefficient
\end{tabular} & $.890^{*}$ & $.543^{*}$ & -.185 \\
\hline & Sig. (2-tailed) & .000 & .002 & .336 \\
\hline & $\mathrm{N}$ & 29 & 29 & 29 \\
\hline \multirow{3}{*}{$\begin{array}{l}\text { Wrong or damaged } \\
\text { good/services } \\
\text { delivered }\end{array}$} & $\begin{array}{l}\text { Correlation } \\
\text { Coefficient }\end{array}$ & $.864^{*}$ & .250 & -.284 \\
\hline & Sig. (2-tailed) & .000 & .218 & .159 \\
\hline & $\mathrm{N}$ & 26 & 26 & 26 \\
\hline \multirow{3}{*}{ Problems with fraud } & $\begin{array}{l}\text { Correlation } \\
\text { Coefficient } \\
\end{array}$ & $.532^{*}$ & .216 & -.431 \\
\hline & Sig. (2-tailed) & .016 & .360 & .058 \\
\hline & $\mathrm{N}$ & 20 & 20 & 20 \\
\hline \multirow{3}{*}{$\begin{array}{l}\text { Complaints and } \\
\text { redress were difficult } \\
\text { or no satisfactory } \\
\text { response received }\end{array}$} & $\begin{array}{l}\text { Correlation } \\
\text { Coefficient } \\
\end{array}$ & $.753^{* \star}$ & .175 & -.251 \\
\hline & Sig. (2-tailed) & .000 & .424 & .247 \\
\hline & $\mathrm{N}$ & 23 & 23 & 23 \\
\hline \multirow{3}{*}{ Technical failure } & $\begin{array}{l}\text { Correlation } \\
\text { Coefficient }\end{array}$ & $.879^{\star \star}$ & $.409^{*}$ & -.083 \\
\hline & Sig. (2-tailed) & .000 & .031 & .674 \\
\hline & $\mathrm{N}$ & 28 & 28 & 28 \\
\hline \multirow{3}{*}{$\begin{array}{l}\text { Difficulties finding } \\
\text { information } \\
\text { concerning } \\
\text { guarantees } \\
\end{array}$} & $\begin{array}{l}\text { Correlation } \\
\text { Coefficient }\end{array}$ & $.749^{* *}$ & .120 & $-.452^{*}$ \\
\hline & Sig. (2-tailed) & .000 & .587 & .030 \\
\hline & $\mathrm{N}$ & 23 & 23 & 23 \\
\hline
\end{tabular}

Due to the fact that the database is made up of a small number of observations (29 states), for the study of the impact of difficulties customers face when ordering online upon the frequency of the buyer, we chose to use a non-parametrical test. Moreover, the characteristic of the variables used for the analysis (quantitative analysis) allows the calculation of the correlation between the variables with the the Spearman test. The results of this test are presented in table no. 2, where for every association between a problem customers faced and the percentage of those who made a purchase within the past 3 months, 3-12 months or more than 12 months.

We start the analysis of the correlation between the frequency of online shopping and the main problems occurring in this field with individuals who purchased online at least one good/service within the past 3 months by comparing the Sig values of column 3 with the chosen significance threshold (0.05). Subsequent to this operation, we reached the conclusion that there are relations (marked *) between the percentage of individuals who faced all six studied problems and those who ordered online within the past 3 months. Moreover, all these correlations are positive, which means that as the percentage of people who face one of the problems presented above when ordering online grows, so will the percentage of those who ordered online within the past 3 months. 
Positive correlations, yet weaker in intensity, are also formed between the individuals who last ordered online within the past 3-12 months and those who waited for a long time for the good/service to be delivered $(S i g=0.002<0.05)$. Moreover, the former category of individuals is significantly influenced by individuals who faced technical difficulties when ordering online $(\mathrm{Sig}=0.031<0.05)$. These two correlations lead to the idea that as the percentage of individuals who faced these two types of problems grows, so will the percentage of those who placed an online order within the 3-12 months time interval.

If we take a look at the last column, where the coefficients of the correlation between the six categories of problems occurring in e-commerce and the percentage of individuals who did not place any online orders within the past year are calculated, we can notice only one correlation (between the percentage of individuals who had difficulties in finding information about guarantees/warranties and those who rarely order online), and this is a negative one (the Sig value $=0.030<0.005$, and the Spearman coefficient $=-0.452$ ). This correlation signifies that as the percentage of individuals who had difficulties in finding information about guarantees/warranties grows, the percentage of those who rarely ordered online will decrease, and vice-versa. In this situation there are two possibilities: either some of the customers who do not order online often stop ordering entirely or order even more rarely, being discouraged by this problem, or they order more often and then the percentage of those who ordered online one year ago will decrease and the percentage of those who purchased something online within the past 3 months and 3-12 months respectively will increase.

\section{Conclusions}

In an ever-developing market, subjected to globalization, it is important that both businesses and decision-makers make sure that e-commerce is carried out fairly. The expansion of this sector needs careful monitoring and analysis due to the huge potential of development it has, but they also need to ensure the safety of online consumers by clearly stating the rights and obligations of each party, by eliminating fraud or ensuring technical maintenance of the online store.

At European level there are significant differences as regards of e-commerce, which occurred due to the different levels of economic growth and level of education of every people. In order for an individual to order a good/service online they first need access to a computer/phone/laptop and to the internet, as well as knowledge to use these devices. Moreover, e-commerce is also influenced by the difficulties the customers face. What is interesting is the fact that as the number of unsatisfied customers increases, so does the number of people who order online more often. Amongst the possible explanations of this phenomenon one can mention the advantages e-commerce has for shoppers, such as: fast shopping at any time of the day or night, fast product/service search, as well as the possibility of comparing prices and the quality of these products/services, and the multitude of choices.

These are only the most important advantages of e-commerce for the consumer, which make him/her overcome the problems he/she faces when shopping online and continue to purchase goods/service in online shops. Despite these, vendors should not neglect the problems occurring along this process because competition is fierce and customer can easily choose someone else. 
The advantages of ecommerce weigh more for the consumer than the problems they face, for example: online shoppers will continue to make online purchases even if they have experienced delays in delivering goods/services, damaged products, online fraud, technical problems, or difficulties in finding information about the warranty of goods/services. Moreover, those who never ordered online are not discouraged by such problems as even as the number of unsatisfied clients grows, the number of those who make frequent online purchases will also grow.

At the opposite end there are the customers who rarely order online and who are not at all influenced by the problems which may occur when ordering online, except difficulties in finding information about guarantees/warrantees and other legal rights, an issue which deters many buyers from purchasing online.

A limitation of this study is the impossibility of conducting these analyzes at the level of each European country as there is insufficient data collected, much of it being accumulated over a period of 10 years, inadequate for formulating relevant conclusions. In few years, this specific shortcoming can transform and it might enable us to creating robust data bases that allow for the study of ecommerce in each European country. This is a proposal for future articles in the field.

\section{References}

Annan K. (2001). Development without borders: globalization in the 21st century. Harvard International Review, 23(2), 84.

Antohi L. (2009). Particularitățile dezvoltării comerțului electronic în Republica Moldova. Analele Științifice ale Univerității de Stat Bogdan Petriceicu Hașdeu din Cahul , V(1857-2170), 232.

Bătăgan L., Mărășescu A., Pocovnicu A. (2010). Drepturile consumatorilor în economia digitală. Studiu de caz al utilizării comerțului electronic în România. Economie teoretică și aplicată, XVII no 9 ( 550), 66.

Benjamin R., Wigand R. (1995, January). Electronic Markets and Virtual Value Chains on the Information Superhighway. Sloan Management Review, 36(2), pp. 31-41.

Brown, M., Pope, N., Voges, K. (2003). Buying or browsing? An exploration of shopping orientations and online purchase intention. European Journal of Marketing , 37 (10/11), 1666-1684.

Bucur C. (2002). Comerț electronic. București: ASE București.

Choi S., Stahl D., Whinston A. (1997). The Economics of Electronic Commerce. Indianapolis: Macmillan Technical Publishing.

Dabidian P., Clausen U., Denecke E. (2016). An Investigation of Behavioural and Structural Characteristics of CEP Service Providers and Freight Demand Considering E-commerce in Germany. Transportation Research Procedia, 14, 2795-2804.

Dennis, C., Fenech, T., Pantano, E., Gerlach, S., Merrilees, B. (2004). E-retailing. Routledge.

Ferri F., Grifoni P., Guzzo T. (2008). Social Aspects of Mobile Technologies on Web Tourism Trend. In Handbook of Research in Mobile Business, Second Edition: Technical, Methodological and Social Perspectives (pp. 293-303). Sydney: Bhuvan Unhelkar . 
Freund C. L., Weinhold D. (2004). The effect of the Internet on international trade. Journal of international economics, 62(1), 171-189.

Gefen D., Straub D. W. (2003). Managing user trust in B2C e-services. E-service Journal, 2(2), 7-24.

Grandon E. E., Pearson J. M. (2004). Electronic commerce adoption: an empirical study of small and medium US businesses. Information \& Management, 42(1), 197-216.

Haleema P. K., lyengar N. C. (2016). A mathematical model with flexible negotiation strategies for agent based negotiations in dynamic e-commerce environments. Journal of King Saud University - Computer and Information Sciences.

Harrington L., Reed G. (1996). Electronic Commerce Finally Comes of Age. The McKinsey Quarterly, 2, 68-69.

Holdorf S., Haasis H. D. (2014, December). Last mile delivery concepts in E-Commerce an empirical approach. The 8th International Conference on Software, Knowledge, Information Management and Applications (SKIMA), 1-6.

Kotler P. (2003). Despre marketing Cum să creăm, cum să câștigăm și cum să dominăm piețele. București : Curier Marketing .

Laudon K. C., Traver C. G. (2013). E-commerce 2012: Business. Technology, Society.

Lixandroiu R. (2017). E-Commerce Trend Forecasting For Romania Vs European Union. Journal of Smart Economic Growth, 2(1).

Malkawi B. H. (2006). E-commerce in light of international trade agreements: The WTO and the United States-Jordan Free Trade Agreement. International Journal of Law and Information Technology, 15(2), 153-169.

McKay J., Marshall, P. (2004). Strategic management of e-business. Brisbane: John Wiley \& Sons.

Nejadirani F., Masoud B., Reza R. (2011). Developing Countries and Electronic Commerce the Case of SMEs. World Applied Sciences Journal, 15(5), 756-764.

Petrovic O., Ksela M., Fallenbock M., Kittl C., Urban G. L., Zobel R. (2003). Trust in the Network Economy (Evolaris, Vol. 2). Santa Clara: Springer-Verlag TELOS.

Savrul M., Incekara A., Sener S. (2014). The potential of E-commerce for SMEs in a globalizing business environment. Procedia-Social and Behavioral Sciences, 150, 35-45.

Seyal A., Rahman M. (2003). A Preliminary Investigation of E-Commerce Adoption in Small \& Medium Enterprises in Brunei. Journal of Global Information Technology Management, 6(2), 6-26.

Surcel T., Dinu V. (2007). Auditul comerțului electronic în relație cu protecția consumatorilor. Amfiteatru economic, 21, 115-120.

Terzi N. (2011). The impact of e-commerce on international trade and employment. Procedia-Social and Behavioral Sciences, 24, 745-753.

Totonchi J., Manshady K. (2012). Relationship between Globalization and E-Commerce. International Journal of e-Education, e-Business, e-Management and e-Learning, 2(1), 83.

Zhou Y., Wang X. (2014). Explore the relationship between online shopping and shopping trips: an analysis with the 2009 NHTS data. Transportation Research Part A: Policy and Practice, 70, 1-9. 